\title{
STRUGGLE OF WOMEN FOR HIGHER EDUCATION
}

\author{
Fathi Habashi* $^{*}$ \\ Laval University, Quebec City, Canada
}

Received 24.07.2017

Accepted 23.08.2017

\begin{abstract}
Higher education was denied for women in most countries mainly by the clergy till the beginning of the $20^{\text {th }}$ century. Universities in most European countries were closed to female students. Few research centers accepted women researchers and similarly few university professors accepted women students. In spite of this many women, chemists and physicists distinguished themselves in great discoveries and women got Nobel Prizes in physics and chemistry. Now, girl graduates from most colleges are twice the number of boys graduates.
\end{abstract}

\section{Introduction}

The situation of women in each society and in each epoch is the level of civilization that society has achieved in that era. The situation of women is the situation of half of the society - the situation of the mother, the sister, the wife, and the daughter. The lawless procedure taken against a woman is the reflection of the lawless state against the foundation of a family and for all the society. If women are educated then it is sure that her children are also educated and a better society is achieved.

Elementary education in Colonial America was widespread in New England, but limited elsewhere. New England Puritans believed it was necessary to study the Bible, so boys and girls were taught to read at an early age. Few girls attended formal schools, but most were able to get some education at home where women taught basic reading and writing skills in their own houses. By 1750, nearly all of New England's women and men could read and write. There was no higher education for women.

In Catholic Austria the job of a woman was 3Ks: Kirche, Kinder, Küche, i.e., go to church, take care of children, and work in the kitchen. In addition to the clergy, were those of the medical profession who objected due to 'menstrual disability'. It was from the late $19^{\text {th }}$ century that progress began to be made. Many believed a higher education was necessary to make women more effective wives, mothers, and teachers but clergymen claimed that women's colleges posed a threat to the family by tempting

* Corresponding author: Fathi Habashi, Fathi.Habashi@arul.ulaval.ca 
women away from their natural and proper role: that of a wife and mother which runs counter to the wisdom and experience of Christendom.

With the start of the Civil War in the US (1861-1865) more opportunities arose for women to fill the empty space in schools and the universities became more willing to admit the women. Slowly more educational institutions opened their doors to women. The Morrill Land-Grant Colleges Act of 1862 founded universities to educate both men and women in practical fields of study, though women's courses were still centered around home economics. By 1870 about a third of colleges were co-educational, later in the 1930s women-only colleges were established that expanded opportunities for courses of study to include more intellectual development as opposed to domestic instruction.

Most universities were closed for women. The University of London is usually credited as the first institution to open its degrees to both sexes on an equal basis (except for medicine) in 1878. Russian universities were closed to women and opened its doors only in 1914. On the other hand, in the United States, society is not burdened with old European prejudices and antiquated institutions. Almira Phelps (1793-1884) was an American educator and author during the $19^{\text {th }}$ century. She published several popular science textbooks in the fields of botany, chemistry, and geology and was the second woman to be elected to the American Association for the Advancement of Science.

However, in 1880 when the American Chemical Society held its Annual Meeting some members brought their wives to the dinner at the banquet but they were refused admission because it was an all men party. When Rachel L. Bodely the only woman member of the society learned about this she immediately resigned. It was eleven years later that the next woman chemist was elected to the Society. In 1919 Irén Götz (18891941) was the first woman lecturer in a Hungarian university. She obtained the doctoral degree and worked at the Curie Laboratory in Paris. In Britain, it was not until 1920 that the Chemical Society would admit women as members. In Germany, girls had no access to the gymnasium, much less the university. Women scientists in Germany were not accepted by the scientific community for a long time. At the University of Berlin, for example, there was not a single woman professor. Nobel Prize winner Max Planck (18581947) (Figure 1) had the opinion that Nature assigned to women the role of mother and housewife and he did not admit women to his lectures. On the other hand, Nobel Prize winner Ernest Rutherford (1871-1937) (Figure 2) did not have anything against women and he is known to have many female coworkers. University regulations at his time necessitated that women sit in the "women's row" in the front of the class.

In 1913, in correspondence with a woman applicant to Harvard Theodore Lyman (1874-1954) that no woman thus far had set foot at the Physics Laboratory. The 1930s saw tremendous changes in women's education at the college level. Home economics and industrial education were new elements of the high school curriculum designed for women's occupations. These classes taught women practical skills such as sewing, cooking, and using the new domestic inventions of the era. But, women were not awarded degrees on an equal basis to men at Cambridge until 1948, partly because if women had degrees they would also have the privileges that came with them, i.e., equal status, voting rights, and a share in the governance of the institution. 


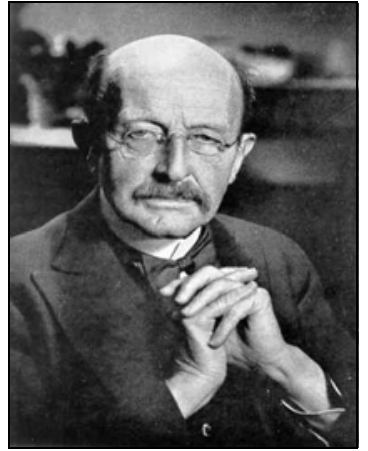

Figure 1 - Max Planck (1858-1947)

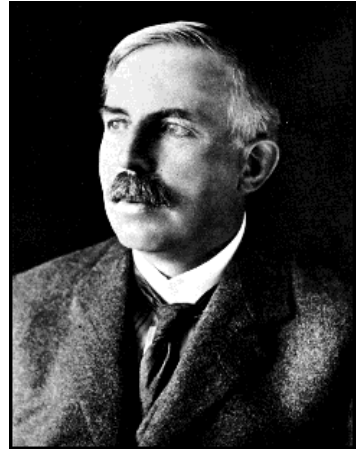

Figure 2 - Ernest Rutherford (1871-1937)

France was somewhat more progressive: The Ministry of Education opened medical schools to women in the late $1860 \mathrm{~s}$, but most university faculties remained male preserves until after the founding of the Third Republic in 1870. It is to be noted that women researchers had to work for a higher degree or in different laboratories after graduation in most cases without salary which is not the case today. Also, women scientists were completely excluded from the Manhattan Project for making the atomic bomb in the US in the period 1942-1946 except perhaps Maria Goeppert-Mayer (see below). Twenty years ago the number of boy students was twice the number of a girl student at colleges. The situation is reversed today - girl students are twice the number of boys.

\section{Curie}

In late 1891 Maria Skłodowska (1867-1934) (Figure 3) left Poland that was occupied by Imperial Russia for France. In 1893, she was awarded a degree in physics and continued studying at the University of Paris. In 1894 summer break, Marie returned to Warsaw thinking that she would be able to work in her chosen field in Poland, but she was denied a place at Kraków University because she was a woman. She returned to Paris to pursue a Ph.D. On July 1895 she married Pierre Curie (18591906) an instructor at the School of Physics and Chemistry in Paris.

Curie's systematic studies included uranium minerals pitchblende and torbernite. She began a systematic search for additional substances that emit radiation when she discovered polonium then radium in 1898. She shared the 1903 Nobel Prize in Physics with her husband Pierre Curie and with physicist Henri Becquerel. She won the 1911 Nobel Prize in Chemistry and was the first woman to become a professor at the Sorbonne. It is natural that Madame Curie encouraged women to work in her laboratory - most of whom were from Poland. 


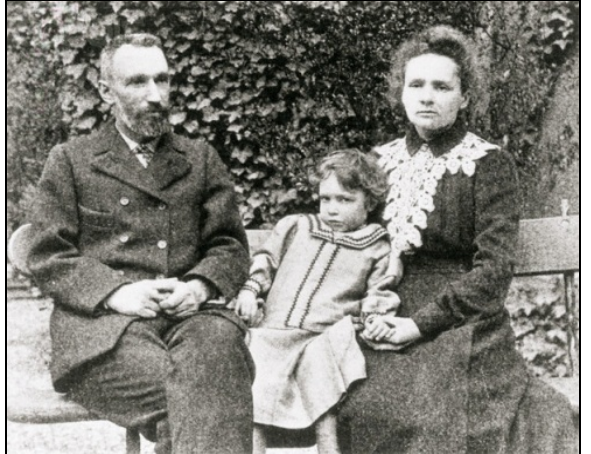

Figure 3 - Pierre and Marie Curie with their daughter Iréne

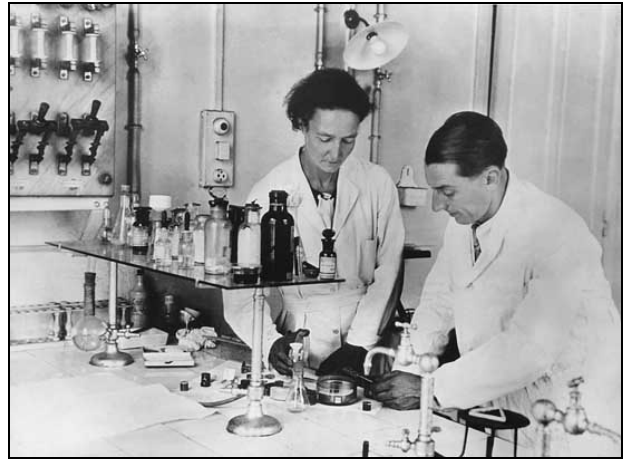

Figure 4 - Iréne Curie and Frédéric Joliot in their laboratory

Her daughter Iréne (1897-1956) is herself a distinguished physicist who got a Nobel Prize for chemistry in 1935 with her husband Frédéric Joliot (1900-1958) (Figure 4) for their discovery of artificial radioactivity. In 1936 when the leftist politician Leon Blum (1872-1950) became Prime Minister in France he appointed women in the government for the first time. He appointed Iréne Curie as Minister for Science.

\section{Brooks}

Harriet Brooks (1876-1933) (Figure 5) was born in Exeter, Ontario, graduated from McGill in Montreal in 1898 and immediately worked with Rutherford for a Master's Degree. She made many discoveries during her research. In 1904 Brooks moved to Barnard College, New York City as a tutor in Physics, and two years later was engaged to be married to a physicist from Columbia. The Dean of the college insisted that Brooks must resign the date of her marriage, saying that the good of the College and for the dignity of the woman. This was common practice at the time. In her resignation letter to the Dean Brooks indignantly commented on the injustice saying that a woman has a right to the practice of her profession and cannot be condemned to abandon it merely because she marries.

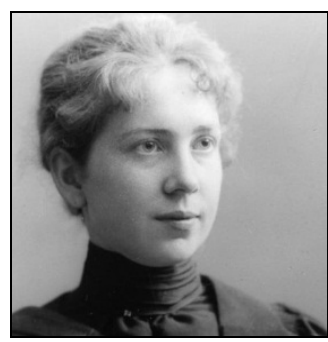

Figure 5 - Harriet Brooks (1876 -1933) 


\section{Meitner}

In Germany, Lise Meitner (1878-1968) (Figure 6) was the second woman to obtain a doctoral degree in physics at the University of Vienna in 1905. She then went to the Friedrich-Wilhelms-Universität in Berlin where Max Planck allowed her to attend his lectures, an unusual gesture by Planck, who until then had rejected any woman wanting to attend his lectures. Meitner had met Planck before when he visited Vienna.

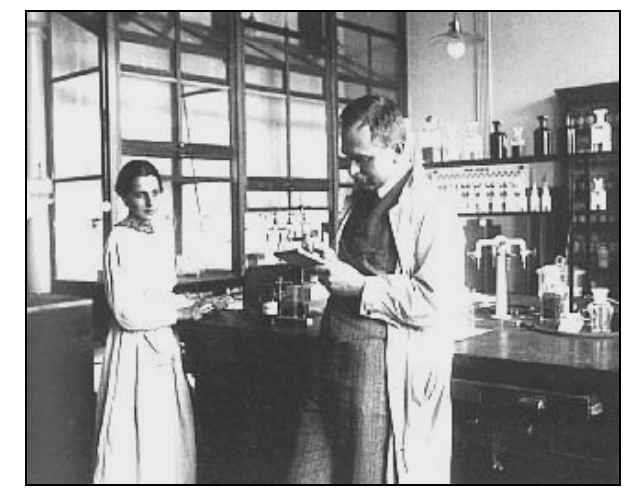

Figure 6 - Lise Meitner (1878-1968) and Otto Hahn (1879-1968) in the laboratory

Meitner then worked together with chemist Otto Hahn (1879-1968) and always signed her papers as L. Meitner. Hahn in his autobiography related that the editor of the German Encyclopedia Brockhaus once wrote to enquire about the address of "Herr" Meitner who became known through "his" articles in Naturwissenschaftliche Rundschau and would request "him" to write an article for the Encyclopedia. When, however, Meitner was identified as Frau Meitner the editor immediately withdrew his offer. Hahn also related that the first time Rutherford met Meitner he greeted her by saying "I thought you were a man". He never expected that a woman would write such good papers. He also related that the head of the Chemistry Institute, Professor Emil Fischer, a Nobel Prize winner, accepted Dr. Lise Meitner as a co-worker to Hahn only on condition that she stayed in her laboratory and did not show up in other places in the Institute where male students were working.

Lise Meitner could not even get the job of a Privatdozent. It was Max Planck who took the step in engaging her as an assistant at the Institute of Theoretical Physics of the University of Berlin. According to Hahn, she might have been the only female scientific assistant in all Prussia. It was also related that when she gave a public lecture on "Problems of Cosmic Physics", the title appeared next day in the newspaper as "Problems in Cosmetic Physics"! Many other stories were told showing how difficult it was for a woman scientist to be accepted in Germany at that time. For example, when Hahn and Meitner were on the street together, colleagues would only say "Guten Tag Herr Hahn", ignoring his companion.

Together with Hahn, she discovered several new isotopes. In 1912 the research group Hahn-Meitner moved to the newly founded Kaiser-Wilhelm-Institute in BerlinDahlem. She worked without salary in Hahn's department of Radiochemistry. It was not 
until 1913, at 35 years old that she got a permanent position with a salary. In 1917, she and Hahn discovered the first long-lived isotope of the element protactinium. In 1926, Meitner became the first woman in Germany to assume a post of full professor in physics, at the University of Berlin. In 1935, she was Head of the Physics Department of the Kaiser Wilhelm Institute for Chemistry in Berlin-Dahlem (today the HahnMeitner Building of the Free University). When the Nazi entered Austria she was forced to leave Berlin to Stockholm. Meitner and her nephew Otto Frisch (1904-1979) correctly interpreted Hahn's and Fritz Strassmann's results as being nuclear fission.

\section{Noddack}

Ida Tacke (1893-1978) (Figure 7) born in Lackhausen bei Wesel in Germany would not hold anything more than research positions, usually unpaid, over the course of her career, after she was married in 1926 to Walter Noddack (1893-1962). She remained a "wife chemist" in the eyes of the professional community. In order to continue her research, and overcome her lack of working space and equipment, Ida Noddack often worked in makeshift laboratories, using equipment borrowed from Walter Noddack and his associates. Her activity evidently depended largely upon Walter Noddack's employment situations, and professionally she remained very much in the shadow of her husband. She discovered the metal rhenium in 1925.

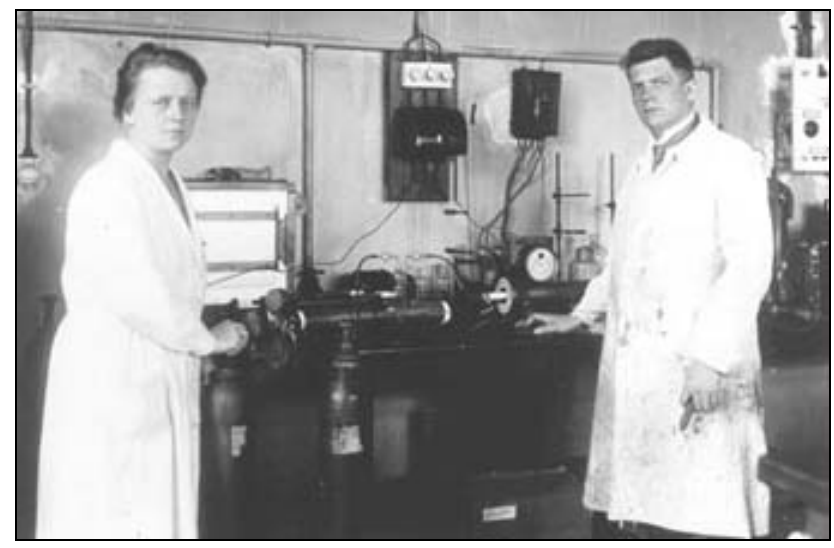

Figure 7 - Ida Noddack (1893-1978) born Tacke with her future husband in the laboratory

\section{Distinguished women scientists}

In 1962, Norway's second female professor Ellen Gleditsch (1879-1968) (Figure 8) was the first woman to receive an honorary doctorate from the Sorbonne in Paris. She worked as an assistant to Marie Curie from 1907 to 1912 and became a pioneer in radiochemistry, establishing the half-life of radium and helping demonstrate the existence of isotopes. Maria Goeppert-Mayer (1906-1972) (Figure 9) was a German-born American theoretical physicist, graduated from the University of Göttingen and worked in 1937 as an unpaid researcher at Columbia University. She won the Nobel Prize in physics in 1963 for proposing the nuclear shell model of the atomic nucleus. She was 
the second woman to win a Nobel Prize in physics after Marie Curie. In 1962 Marguerite Perey (1909-1975) (Figure 10) became the first woman to be elected correspondante of the Académie des Sciences an honour denied to Marie Curie and Irene Joliot-Curie. In 1939, Perey discovered the element francium by purifying samples of lanthanum that contained actinium. Since 2015 Nobel Prizes were won by 48 women. It should be mentioned that Marie Curie won two Nobel Prizes: one in physics in 1903 and one in chemistry in 1911.

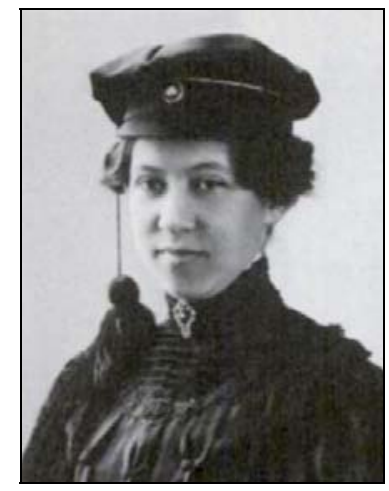

Figure 8 - Ellen Gleditsch (1879-1968)

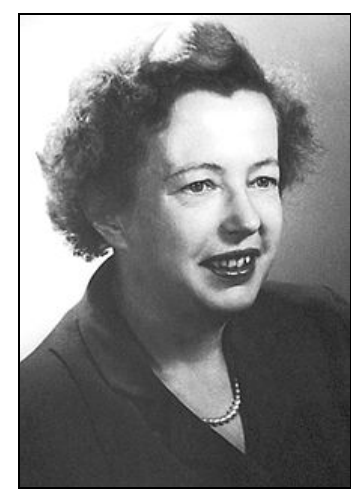

Figure 9 - Maria Goeppert-Mayer (1906-1972)

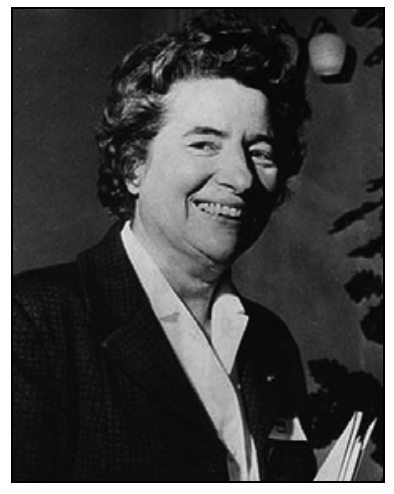

Figure 10- Marguerite Perey (1909-1975)

\section{Conclusion}

A woman has the same right as a man to develop her abilities and to employ them freely. She is a human being as well as man. The progress of humanity consists in the equality of sexes. Humanity and society consist of both sexes; both are indispensable to their maintenance and development. Already women have removed many barriers and have entered the intellectual arena in some countries with marked success.

\section{Acknowledgement}

I am most grateful to Marelene F. Rayner-Canham of Memorial University in Newfoundland, Canada whose excellent contributions on this subject inspired me to write this article.

\section{References}

- W. Ley, Otto Hahn. A Scientific Autobiography, Scribner, New York 1966

- M. F. Rayner-Canham and G.W. Rayner-Canham, A Devotion to Their Science, Chemical Heritage Foundation [Philadelphia] and McGill Queens's University Press [Montreal] 1997 - M. F. Rayner-Canham and G.W. Rayner-Canham, Women in Chemistry, American Chemical Society, Washington, DC 1998

- F. Habashi, Ida Noddack (1896-1978), Métallurgie Extractive Québec 2005. Distributed by Laval University Bookstore, www.zone.ul.ca

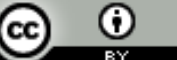

Creative Commons License

This work is licensed under a Creative Commons Attribution 4.0 International License. 